\section{Acetaldehyde and Ethanol Metabolism during Conditioning and Air Storage of 'Honeycrisp' Apples}

\author{
Yosef Al Shoffe, Abdul Sattar Shah ${ }^{1}$, Jacqueline F. Nock, \\ and Christopher B. Watkins ${ }^{2}$ \\ Horticulture Section, School of Integrative Plant Science, Plant Science \\ Building, Cornell University, Ithaca, NY 14853
}

Additional index words. Malus domestica Borkh., internal ethylene concentration, volatiles, alcohol dehydrogenase, pyruvate decarboxylase, soft scald, DA meter

\begin{abstract}
Honeycrisp' apples are susceptible to the physiological disorder soft scald, especially when stored at temperatures close to $0{ }^{\circ} \mathrm{C}$. The disorder can be reduced by a conditioning treatment of $10^{\circ} \mathrm{C}$ for 7 days before storage, but little is known about the underlying physiology of disorder development. The effects of storing 'Honeycrisp' apples in air at $0.5^{\circ} \mathrm{C}$ for a total of 140 days, without and with conditioning, on internal ethylene concentration (IEC), ethanol and acetaldehyde concentrations, and activities of alcohol dehydrogenase (ADH) and pyruvate decarboxylase (PDC) were investigated in relation to soft scald incidence. Fruit were selected on the basis of background color (chlorophyll concentration) using a nondestructive delta absorbance (DA) meter to minimize variability of fruit maturation. Conditioning reduced soft scald incidence to $1 \%$ compared with $28 \%$ in unconditioned fruit. During the conditioning period, IECs were usually greatest in the conditioned fruit, with no effect on ethanol and acetaldehyde concentrations. During subsequent storage, IEC was greatest in conditioned fruit, whereas ethanol and acetaldehyde concentrations were generally less. However, ADH and PDC activities were unaffected consistently by conditioning or during storage.
\end{abstract}

'Honeycrisp' apples can be highly susceptible to the development of low temperature storage disorders such as soft scald (an external injury) and soggy breakdown (an internal injury) (Lachapelle et al., 2013, 2017; Tong et al., 2003; Wargo and Watkins, 2004; Watkins et al., 2004, 2005). Fruit can develop either one or both disorders, and they apparently represent different expressions of low temperature injury. Also, soggy breakdown may be a variant of low temperature breakdown, the more common low temperature disorder (Wills and Scott, 1970). In Nova Scotia, low temperature injury in 'Honeycrisp' is predominantly expressed as low

Received for publication 24 Apr. 2018. Accepted for publication 9 July 2018.

This research was supported in part by the U.S. Department of Agriculture (USDA) National Institute of Food and Agriculture, Hatch project 2013-14-483, Improving Quality and Reducing Losses in Specialty Fruit Crops through Storage Technologies (NE-1336).

Any opinions, findings, conclusions, or recommendations expressed in this publication are those of the authors and do not necessarily reflect the view of the National Institute of Food and Agriculture or the USDA. Abdul Sattar Shah was supported by the Higher Education Commission of Pakistan under the "International Research Support Initiative Program."

${ }^{1}$ Current address: Director Technical \& Scientific Analysis, KP-Food Safety \& Halal Food Authority Government of Khyber Pakhtunkhwa, Peshawar, Pakistan.

${ }^{2}$ Corresponding author. E-mail: chris.watkins@, cornell.edu. temperature breakdown (DeLong et al., 2006). typically occurs within the first 6 to 8 weeks of storage and is not progressive after removal to warm temperatures. More mature fruit have greater susceptibility to disorder development, although effects of harvest date can be inconsistent (Moran et al., 2010; Tong et al., 2003; Watkins et al., 2005). Recently, a new indicator of harvest maturity, the delta absorbance (DA) meter, which assesses changes in background skin color (chlorophyll concentration) of the fruit, has been developed and tested on several cultivars, including 'Empire', 'Granny Smith', 'Golden Delicious', 'Pink Lady', and 'Red Delicious' (Cocetta et al., 2017; Doerflinger et al., 2016; Nyasordzi et al., 2013). Low readings, which indicate a more yellow background color (low chlorophyll concentrations) and advanced maturity are associated with high soft scald susceptibility in 'Honeycrisp' apples (unpublished data).

An obvious strategy to avoid low temperature storage disorders is to increase storage temperatures, but soggy breakdown and soft scald can develop even at 2 to $3{ }^{\circ} \mathrm{C}$ in lateharvested fruit (Moran et al., 2010; Watkins et al., 2004, 2005). The discovery that soft scald development in 'Honeycrisp' apples can be controlled by a conditioning period of $7 \mathrm{~d}$ at $10{ }^{\circ} \mathrm{C}$ (Watkins and Rosenberger, 2000) was confirmed by subsequent research (DeLong et al., 2004, 2009; Moran et al., 2010; Watkins et al., 2004), although control may not always be complete, especially in more mature fruit stored at temperatures less Regardless of expression type, incidence than $3{ }^{\circ} \mathrm{C}$ (Moran et al., 2010; Watkins et al., 2004). Conditioning has little effect on quality factors such as flesh firmness, titratable acidity (TA), and soluble solids concentrations (SSC), although bitter pit incidence and skin greasiness may increase (DeLong et al., 2006, 2009; Watkins et al., 2004). Conditioning is widely used by commercial 'Honeycrisp' storage operators to reduce risk of disorder development.

The etiology of soft scald development is not well understood, nor is the mechanism by which conditioning can decrease the disorder. Soft scald incidence is related to oxidation of unsaturated fatty acids in the surface lipids and elevated hexanol concentrations in fruit (Hopkirk and Wills, 1981). Untargeted metabolic profiling of 'Honeycrisp' apples with varying degrees of susceptibility to soft scald revealed changes in a number of distinct pathways preceding and concurrent with disorder development, including elevated $\gamma$-aminobutyric acid (GABA), 1-hexanol, acylated steryl glycosides, and free rho-coumaryl acyl esters (Leisso et al., 2013, 2015, 2016). Tissues of fruit with soggy breakdown have greater concentrations of GABA, glycerol, sitosteryl (6-O-palmitoyl)-d-glucoside and sitosteryl (6-O-stearate)-d-glucoside, and triacylglycerides containing combinations of $16: 0,18: 3,18: 2$, and 18:1 fatty acids than fruit without injury (Leisso et al., 2013, 2015, 2016). A proteomic study on 'Ambrosia', an apple cultivar also susceptible to soft scald, revealed metabolic differences in fruit that were conditioned compared with unconditioned fruit (Luo et al., 2018). However, the reduction of soft scald incidence with conditioning was trivial, and therefore it is uncertain that metabolic differences are really meaningful in relation to disorder incidence.

At harvest and under aerobic storage conditions, apples usually have low acetaldehyde and ethanol concentrations, as well as low pyruvate decarboxylase (PDC) and alcohol dehydrogenase (ADH) activities (Pesis, 2005). Both compounds are precursors of aroma volatiles in apple fruit, with the activity of alcohol acyltransferase being the last step of volatile compound synthesis to produce esters from alcohols (Espino-Diaz et al., 2016). Ethanol can accumulate in apples if left on the tree and harvested late (Nichols and Patterson, 1987), but most focus on the fermentation pathway, which is centered on anaerobic metabolism during the postharvest period (Pesis, 2005). Accumulation of acetaldehyde and ethanol is associated with stress, typically low oxygen and/or high carbon dioxide concentrations in the storage atmosphere (Saquet and Streif, 2008) or when skin coatings are applied (Bai et al., 2003). However, acetaldehyde and ethanol accumulations have been associated with physiologic disorders, including low temperature injuries and soft scald (Lyons, 1973; Miller, 1936; Thomas, 1931), although it is unclear whether acetaldehyde is a cause or a result of disorder development (Smagula and Bramlage, 1977). 
Watkins et al. (2004) found that ethanol concentrations in cortical tissues of 'Honeycrisp' apples were greater in those stored at $0.5^{\circ} \mathrm{C}$ than at $2.8{ }^{\circ} \mathrm{C}$, and lowest in conditioned fruit after storage at either temperature. Although Leisso et al. (2015) found tissues of fruit with soggy breakdown, ethanol was not higher in fruit with soft scald (Leisso et al., 2016). In contrast, we have consistently found high acetaldehyde and ethanol concentrations in peel tissues of 'Honeycrisp' fruit with soft scald (unpublished data).

The primary objective of this study was to trations, and activities of PDC and $\mathrm{ADH}$, with soft scald development in 'Honeycrisp' fruit stored in air at $0.5{ }^{\circ} \mathrm{C}$ with and without fruit with greater risk of disorder susceptibility and to minimize variation of fruit maturity within the experimental treatments.

\section{Materials and Methods}

Plant material. The fruit from nine 'Honeycrisp' apple (Malus domestica Borkh.) trees (16 years old, grafted on M.9 rootstock, at the Cornell Orchard, Ithaca, NY) were strip-picked on 20 Sept. 2015. Uniform size and unblemished fruit were then sorted in the laboratory using a DA meter (TR Turoni srl, Forli, Italy). Each fruit was measured on the unblushed and blushed side, and then separated into DA categories. A total of 568 fruit from DA meter category 0.2 to 0.4 were randomly allocated into six replicates. Three replicates were stored at $0.5^{\circ} \mathrm{C}$ immediately, and three replicates were conditioned in air at $10{ }^{\circ} \mathrm{C}$ for $7 \mathrm{~d}$ and then stored at $0.5^{\circ} \mathrm{C}$.

Fruit sampling. Three replicates of five fruit were used at harvest for initial assessments. The internal ethylene concentration (IEC) of each fruit was measured for 1-mL gas samples taken from the core of each apple and injected into a Hewlett-Packard 5890 series II gas chromatograph (HewlettPackard, Wilmington, DE), as described by Watkins et al. (2000). Firmness was measured on opposite peeled sides of each fruit using a Guss Fruit Texture Analyzer [Guss Manufacturing (Pty) Ltd., Strand, South Africa] fitted with an 11.1-mm-diameter probe, and the expressed juice was used for measurement of the SSC with a PR-100 refractometer (Atago Co. Ltd., Tokyo, Japan). TA was measured by titrating the juice to $\mathrm{pH} 8.1$ with $0.1 \mathrm{~m} \mathrm{NaOH}$ (Mettler DL 12 Titrator, Hightstown, NJ). The starch pattern index (SPI) of each fruit cut at the equator was assessed using the Cornell generic chart in which 1 represents $100 \%$ stained starch and 8 represents $0 \%$ stained starch (Blanpied and Silsby, 1992).

Five fruit were sampled from each replicate at $0,2,5,7,8,14,21,35,56,77,105$, and $140 \mathrm{~d}$ (during conditioning and during air storage at $0.5{ }^{\circ} \mathrm{C}$ ). Each replicate was removed from cold storage immediately before measurement of IEC and peeling, and was elevated ethanol concentrations in cortical compare acetaldehyde and ethanol concenconditioning. We used the DA meter to select processed rapidly to ensure that warming of fruit was minimized. Each fruit was peeled by taking skin from the stem to the calyx, and was immediately dropped into liquid nitrogen. Samples were stored at $-80^{\circ} \mathrm{C}$ until they were ground in liquid nitrogen using an A11 analytical grinding mill (IKA Works, Wilmington, NC) (Lee et al., 2012). The fine powder was stored at $-80{ }^{\circ} \mathrm{C}$.

Acetaldehyde and ethanol. Five grams of powder was added to $2.5 \mathrm{~g}$ saturated $\mathrm{NaCl}$ in 20-mL vials fitted with septa, and were kept at $-20{ }^{\circ} \mathrm{C}$ until further use. The vials were heated in a dry bath incubator (Fisher Scientific Co., Waltham, MA) at $80{ }^{\circ} \mathrm{C}$ for 20 minutes. A headspace sample of $0.5 \mathrm{~mL}$ was analyzed using a gas chromatograph (Agilent 6850, Agilent, Santa Clara, CA) with Agilent ChemStation version B.04.01 software on a Hewlett Packard Compaq computer. A $15-\mathrm{m} \times 0.53$-mm-i.d. Restek wide-bore capillary column coated with $1.0 \mu \mathrm{m}$ Stabilwax (Resteck Corp., Bellefonte, PA) was used. The carrier gas was high-purity helium at 6 $\mathrm{mL} \cdot \mathrm{min}^{-1}$, with hydrogen at $40 \mathrm{~mL} \cdot \mathrm{min}^{-1}$ and compressed air at $400 \mathrm{~mL} \cdot \mathrm{min}^{-1}$. The inlet and detector temperatures were $220{ }^{\circ} \mathrm{C}$ and $245{ }^{\circ} \mathrm{C}$, respectively. The temperature program was held at $40^{\circ} \mathrm{C}$ for $4 \mathrm{~min}$, increased to $200{ }^{\circ} \mathrm{C}$ at $30^{\circ} \mathrm{C} \cdot \mathrm{min}^{-1}$, and was held for $5 \mathrm{~min}$ before cooling to $40{ }^{\circ} \mathrm{C}$ as described by Fernandez-Trujillo et al. (2001). Areas with identical retention times were compared with standard curves for ethanol and acetaldehyde. Concentrations are presented as milligrams per kilogram on a fresh weight basis.

$A D H$ and PDC enzyme extraction and measurement. A total of $0.4 \mathrm{~g}$ frozen powder was extracted using $1 \mathrm{~mL} 85 \mathrm{~mm} 2-(\mathrm{N}-$ morpholino)ethanesulfonic acid (MES) $\mathrm{pH}$ 6.0, $5 \mathrm{~mm}$ dithiothreitol, $1 \mathrm{~mm}$ phenylmethylsulfonylfluoride, $1 \%(\mathrm{w} / \mathrm{v})$ polyvinylpyrrolidone, and $0.1 \%(\mathrm{v} / \mathrm{v})$ Triton $\mathrm{X}-100$. The mixture was homogenized using a vortex and filtered with two layers of cheesecloth into Eppendorf tubes. The mixture was centrifuged at $25,000 g_{\mathrm{n}}$ for $15 \mathrm{~min}$ at $4{ }^{\circ} \mathrm{C}$ (Allegra 64R Centrifuge; Beckman Coulter Co., Palo Alto, CA), and the supernatant was kept in ice.

PDC activity was measured according to Echeverria et al. (2004) by following decreasing absorbance at $340 \mathrm{~nm}$ for $6 \mathrm{~min}$ at
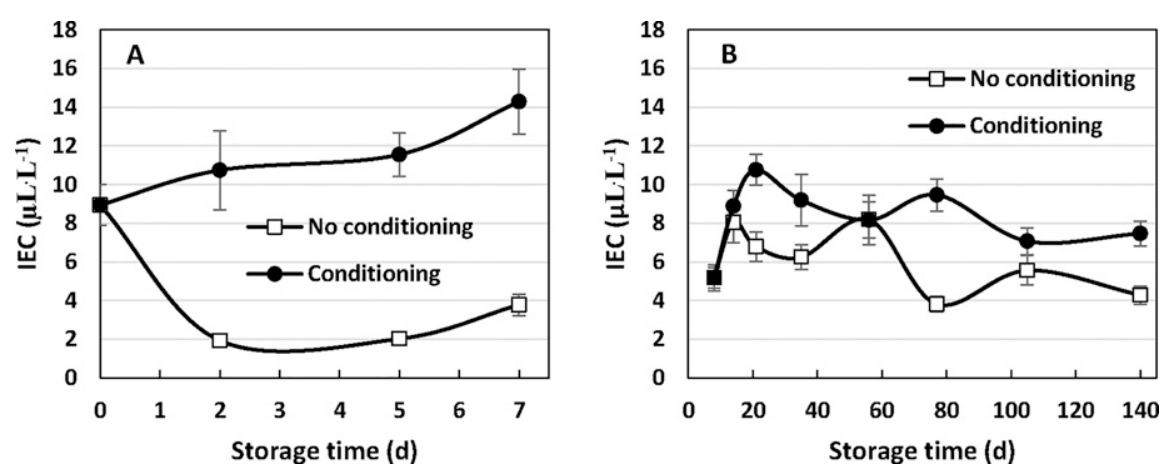

Fig. 1. Internal ethylene concentration (IEC) in 'Honeycrisp' apples stored at $0.5^{\circ} \mathrm{C}$ (no conditioning) or $10{ }^{\circ} \mathrm{C}$ for $7 \mathrm{~d}$ (conditioning) (A), and then stored at $0.5^{\circ} \mathrm{C}$ for up to $140 \mathrm{~d}(\mathbf{B})$. Data are presented as means \pm SE $(n=5)$.

$25^{\circ} \mathrm{C}$ using a spectrophotometer (Genesys $10 \mathrm{~S}$ UV-Vis; Thermo Fisher Scientific, Madison, WI). The reaction was started by adding $100 \mu \mathrm{L}$ enzyme extract to a solution of $2.3 \mathrm{~mL}$ thiamine pyrophosphate (TPP)$\mathrm{MgCl}_{2}$ solution (5 mM TPP, $50 \mathrm{~mm} \mathrm{MgCl}_{2}$ in MES, pH 6.0), $300 \mu \mathrm{L} 50 \mathrm{~mm}$ pyruvate, $150 \mu \mathrm{L} 0.85 \mathrm{~mm} \beta-\mathrm{NADH}$, and $150 \mu \mathrm{L}$ ADH enzyme (200 U). One unit converted $1 \mu \mathrm{mol}$ pyruvate to acetaldehyde per minute, and activity is expressed as unit per milligram protein.

ADH activity was measured according to Kagi and Vallee (1960) by using $1.3 \mathrm{~mL}$ 50 mm sodium pyrophosphate buffer, $\mathrm{pH} 8.8$, $100 \mu \mathrm{L} 75 \mathrm{~mm}$ ethanol, $1.5 \mathrm{~mL} 5 \mathrm{~mm} \beta-\mathrm{NAD}$, and $100 \mu \mathrm{L}$ of the enzyme extract. Increasing absorbance at $340 \mathrm{~nm}$ was recorded up to 6 min at $25^{\circ} \mathrm{C}$. One unit converted $1 \mu \mathrm{mol}$ ethanol to acetaldehyde per minute, and activity is expressed as unit per milligram protein.

Protein concentrations were measured according to the Bradford (1976) method, using a bovine serum albumin standard curve.

Physiologic disorders. The remaining fruit from each replicate, an average of 35 fruit, were assessed for presence or absence of soft scald and soggy breakdown, as well as any other disorders, as percentages, after $140 \mathrm{~d}+7 \mathrm{~d}$ at $20{ }^{\circ} \mathrm{C}$. Each fruit was cut four to five times from the calyx to the stem.

Statistical analysis. Student's $t$ test was used to compare means at the $5 \%$ confidence level. All statistics were carried out using the JMP statistical program $\left(J M P^{\circledR} 12\right.$ Copyright (C) 2015, SAS Institute Inc., Cary, NC). Percentage data were arcsine-transformed for analysis and presented as back-transformed means. Data are presented as means \pm SE of means $(n=5)$.

\section{Results}

The harvest indices for the fruit in the 0.2to $0.4-\mathrm{DA}$ meter category were $8.9 \mu \mathrm{L} \cdot \mathrm{L}^{-1}$ IEC, $58 \mathrm{~N}$ flesh firmness, $12.8 \% \mathrm{SSC}$, and $0.55 \%$ TA, with an SPI of 8 .

The IEC of fruit placed immediately into cold storage decreased rapidly, but then increased to $3.8 \mu \mathrm{L} \cdot \mathrm{L}^{-1}$, whereas that of fruit kept at $10^{\circ} \mathrm{C}$ for $7 \mathrm{~d}$ increased to $14.3 \mu \mathrm{L} \cdot \mathrm{L}^{-1}$ (Fig. 1A). After $24 \mathrm{~h}$ of cold storage, the IEC 
of fruit from untreated and conditioning treatments were both $5.8 \mu \mathrm{L} \cdot \mathrm{L}^{-1}$ (Fig. 1B). The IEC then fluctuated during cold storage, with the IEC of the conditioned fruit usually greater than that of the unconditioned fruit (Fig. 1B). Over all sampling times, the IEC of fruit during conditioning was $11.4 \mu \mathrm{L} \cdot \mathrm{L}^{-1}$ compared with $4.2 \mu \mathrm{L} \cdot \mathrm{L}^{-1}$ in unconditioned fruit $(P<0.001)$, and during storage was 8.3 $\mu \mathrm{L} \cdot \mathrm{L}^{-1}$ in conditioned fruit compared with $6.0 \mu \mathrm{L} \cdot \mathrm{L}^{-1}$ in unconditioned fruit $(P<0.001)$.

Acetaldehyde concentrations in fruit stayed stable during the conditioning period. Over all sampling times, concentrations were unaffected by treatment, although they tended to be slightly greater in fruit placed directly in storage at $0.5{ }^{\circ} \mathrm{C}$ (Fig. 2A). Ethanol concentrations were unaffected by conditioning (Fig. 2C). Both acetaldehyde and ethanol concentrations fluctuated during subsequent cold storage, but were generally greater in fruit placed directly in storage at $0.5^{\circ} \mathrm{C}$ than in conditioned fruit (Fig. 2B and D). Over all sampling times, acetaldehyde concentrations during storage were $1.9 \mathrm{mg} \cdot \mathrm{kg}^{-1}$ in conditioned fruit compared with $3.5 \mathrm{mg} \cdot \mathrm{kg}^{-1}$ in unconditioned fruit $(P<0.01)$, and for ethanol were $25 \mathrm{mg} \cdot \mathrm{kg}^{-1}$ in conditioned fruit compared with $46 \mathrm{mg} \cdot \mathrm{kg}^{-1}$ in unconditioned fruit $(P<0.01)$. No consistent effects of conditioning treatment on PDC or ADH activity were detected, either during the conditioning period or during cold storage (Fig. 3A-D)

At the final sampling time of $140 \mathrm{~d}$, soft scald incidence of fruit kept at $0.5{ }^{\circ} \mathrm{C}$ was $28 \%$ compared with $1 \%$ in the conditioned fruit. No soggy breakdown was detected. Low incidences of bitter pit, senescent breakdown, and wrinkly skin were observed in fruit of both treatments, but were not statistically different (data not shown).

\section{Discussion}

Most recommendations for postharvest handling of apple fruit have focused on rapid cooling to reduce ripening and senescence processes (Watkins, 2017). However, stepwise cooling has been recommended for control of core browning in 'Granny Smith', but with some loss of fruit condition (Little and Holmes, 2000). Similarly, a storage regimen of $10{ }^{\circ} \mathrm{C}$ for $10 \mathrm{~d}, 4^{\circ} \mathrm{C}$ for the next $20 \mathrm{~d}$, and $0{ }^{\circ} \mathrm{C}$ for the remaining $150 \mathrm{~d}$ resulted in the least superficial scald incidence in fruit without 1-methylcyclopropene treatment (Moggia et al., 2009). We found that fruit with conditioning had lower soft scald incidence than unconditioned fruit. Soft scald and soggy breakdown are thought to be low temperature/chilling injuries (CIs) (Pierson et al., 1971; Smock, 1977), as is superficial scald (Watkins et al., 1995). The effects of delayed cooling, step-down cooling, or conditioning periods are therefore consistent with similar effects on reducing CI incidence of other fruit types; these are used commercially when effects on fruit quality are not negative. The biochemical changes underlying the effects of conditioning on disorders
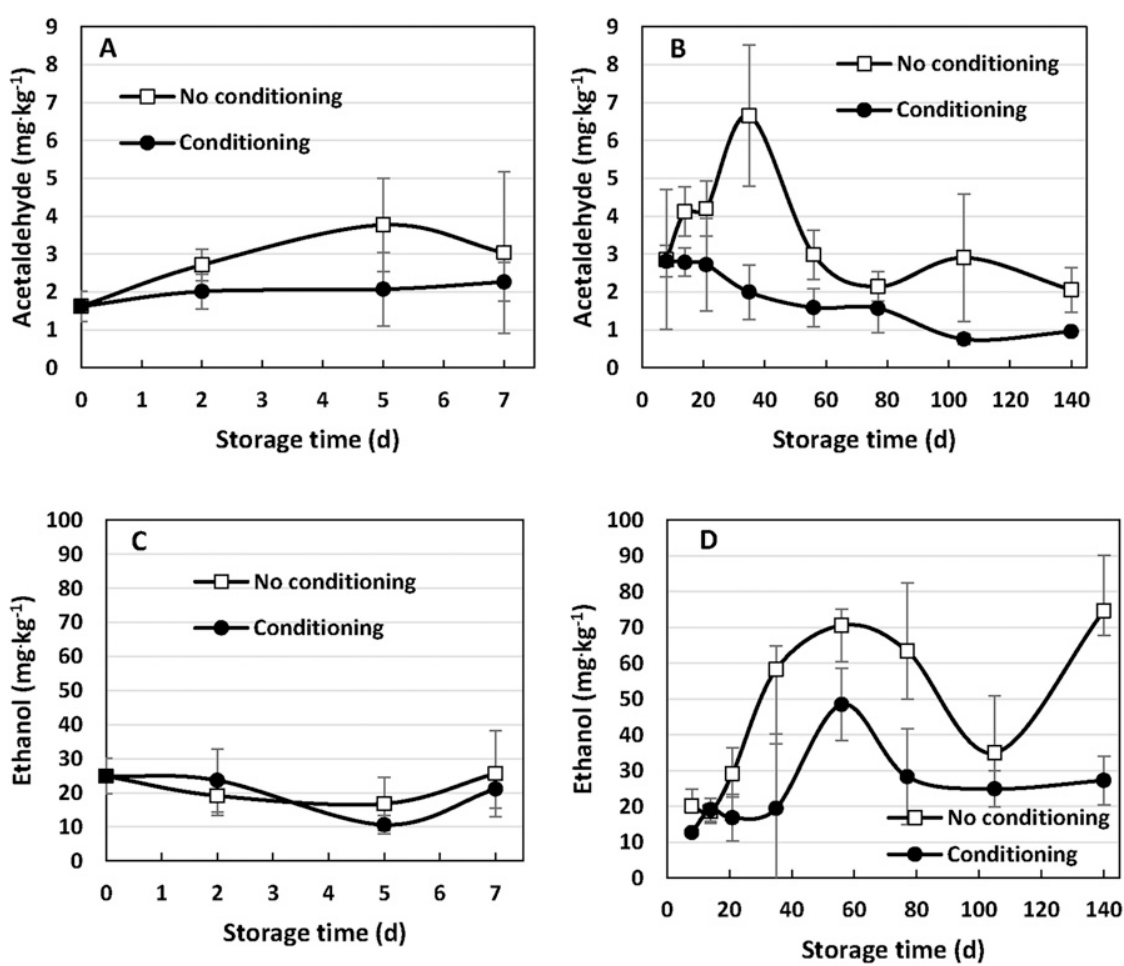

Fig. 2. Acetaldehyde $(\mathbf{A}, \mathbf{B})$ and ethanol $(\mathbf{C}, \mathbf{D})$ concentrations of 'Honeycrisp' apples stored at $0.5^{\circ} \mathrm{C}(\mathrm{no}$ conditioning) or $10^{\circ} \mathrm{C}$ for $7 \mathrm{~d}$ (conditioning) $(\mathbf{A}, \mathbf{C})$, and then stored at $0.5^{\circ} \mathrm{C}$ for up to $140 \mathrm{~d}(\mathbf{B}, \mathbf{D})$. Data are presented as means \pm SE $(n=5)$.
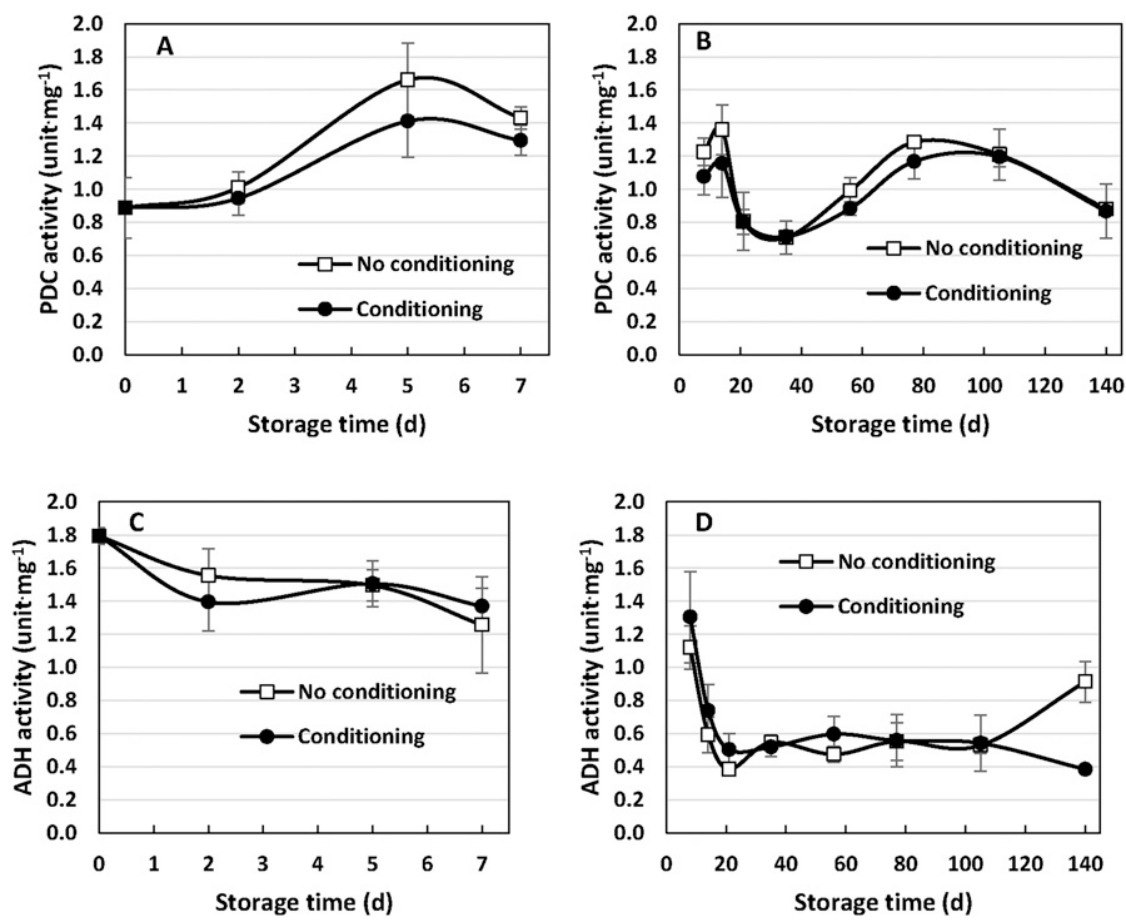

Fig. 3. Pyruvate decarboxylase (PDC) and alcohol dehydrogenase (ADH) activity in 'Honeycrisp' apples stored at $0.5^{\circ} \mathrm{C}$ (no conditioning) or $10^{\circ} \mathrm{C}$ for $7 \mathrm{~d}$ (conditioning) $\left(\mathbf{A}, \mathbf{C}\right.$ ), and then stored at $0.5^{\circ} \mathrm{C}$ for up to $140 \mathrm{~d}(\mathbf{B}, \mathbf{D})$. Data are presented as means $\pm \operatorname{SE}(n=5)$.

are not understood, but appear to involve a complex interaction between the effects of maturity and ripening on postharvest changes. For stone fruit, for example, advancing ripening processes appear to be associated with lower CI incidence (Lurie and Crisosto, 2005). In the current study, fruit had greater IECs during conditioning than without conditioning, and these greater IECs were found during the remainder of time in storage, suggesting that a greater rate of metabolism was induced by conditioning. 
Conditioned fruit also had lesser ethanol and acetaldehyde accumulations than those found in unconditioned fruit during the cold storage period, but had no consistent effects on PDC and ADH activities. The relationships between fermentation products, especially acetaldehyde, and storage disorders has been the subject of debate (Smagula and Bramlage, 1977). Acetaldehyde is regarded as a more toxic compound than ethanol (Chervin et al., 1999). A feature of soggy breakdown and soft scald has been acetaldehyde and ethanol accumulations (Miller, 1936; Smagula and Bramlage, 1977; Thomas, 1931), and ethanol accumulation is associated with incidence of both disorders in 'Honeycrisp' apples (Watkins et al., 2004). Although Leisso et al. $(2016,2017)$ found that ethanol accumulation was more consistently associated with soggy breakdown than with soft scald, we have consistently observed accumulations of ethanol in peel tissues of fruit with soft scald (Al Shoffe et al., 2017). Conditioning reduces soft scald incidence in fruit, but the mechanism by which conditioning inhibits development of the disorder is not known.

The absence of relationships between acetaldehyde and ethanol accumulation and associated enzyme activities is not uncommon. Examples include kiwifruit and pear, in which $\mathrm{ADH}$ activity was less during storage despite an increase in ethanol accumulation (Botondi et al., 2012; Lara et al., 2003). Even less ADH activity may be enough for ethanol production (Chervin et al., 1999; Echeverria et al., 2004; Prestage et al., 1999).

In conclusion, the reduction of soft scald incidence by conditioning supports the view that the disorder is a CI. The effects of conditioning were associated with greater IECs and presumably faster metabolism. Conditioning resulted in lesser acetaldehyde and ethanol concentrations in 'Honeycrisp', but no consistent effects on ADH and PDC activities, during storage. More research to understand the metabolic effects of conditioning on fruit is needed.

\section{Literature Cited}

Al Shoffe, Y., J.F. Nock, and C.B. Watkins. 2017. Ethanol accumulation does not predict soft scald in 'Honeycrisp' apples. NY Fruit Qrtly. 25(2):25-29.

Bai, J.H., R.D. Hagenmaier, and E.A. Baldwin. 2003. Coating selection for 'Delicious' and other apples. Postharvest Biol. Technol. 28:381-390.

Blanpied, G.D. and K.J. Silsby. 1992. Predicting harvest date windows for apples. Cornell Coop. Ext. Bul. 221.

Botondi, R., V. Russo, and F. Mencarelli. 2012. Anaerobic metabolism during short and long term storage of kiwifruit. Postharvest Biol. Technol. 64:83-90.

Bradford, M. 1976. A rapid and sensitive method for the quantitation of microgram quantities of protein utilizing the principle of protein-dye binding. Anal. Biochem. 72:248-254.

Chervin, C., J.K. Truett, and J. Speirs. 1999. Alcohol dehydrogenase expression and alcohol production during pear ripening. J. Amer. Soc. Hort. Sci. 124:71-75.
Cocetta, G., R. Beghi, I. Mignani, and A. Spinardi. 2017. Nondestructive apple ripening stage determination using the delta absorbance meter at harvest and after storage. HortTechnology 27:54-64.

DeLong, J.M., R.K. Prange, and P.A. Harrison. 2004. The influence of pre-storage delayed cooling on quality and disorder incidence in 'Honeycrisp' apple fruit. Postharvest Biol. Technol. 33:175-180.

DeLong, J.M., R.K. Prange, P.A. Harrison, C.G. Embree, D.S. Nichols, and A.H. Wright. 2006. The influence of crop-load, delayed cooling and storage atmosphere on post-storage quality of 'Honeycrisp'TM apples. J. Hort. Sci. Biotechnol. 81:391-396.

Delong, J.M., R.K. Prange, W.C. Schotsmans, D.S. Nichols, and P.A. Harrison. 2009. Determination of the optimal pre-storage delayed cooling regime to control disorders and maintain quality in 'Honeycrisp'TM apples. J. Hort. Sci. Biotechnol. 84:410-414.

Doerflinger, F.C., J.F. Nock, Y. Al Shoffe, X. Shao, and C.B. Watkins. 2016. Non-destructive maturity assessment of 'Empire' apples treated with preharvest inhibitors of ethylene perception and production with a delta absorbance (DA) meter. Acta Hort. 1119:227-233.

Echeverria, G., J. Graell, M.L. Lopez, and I. Lara. 2004. Volatile production, quality and aromarelated enzyme activities during maturation of 'Fuji' apples. Postharvest Biol. Technol. 31:217-227.

Espino-Diaz, M., D.R. Sepulveda, G. GonzalezAguilar, and G.I. Olivas. 2016. Biochemistry of apple aroma: A review. Food Technol. Biotechnol. 54:375-394.

Fernandez-Trujillo, J.P., J.F. Nock, and C.B. Watkins. 2001. Superficial scald, carbon dioxide injury, and changes of fermentation products and organic acids in 'Cortland' and 'Law Rome' apples after high carbon dioxide stress treatment. J. Amer. Soc. Hort. Sci. 126:235241.

Hopkirk, G. and R.B.H. Wills. 1981. Variation in fatty acid composition of apples in relation to soft scald. Phytochemistry 20:193-195.

Kagi, J.H.R. and B.L. Vallee. 1960. Role of zinc in alcohol dehydrogenase: 5. Effect of metalbinding agents on the structure of the yeast alcohol dehydrogenase molecule. J. Biol. Chem. 235:3188-3192.

Lachapelle, M., G. Bourgeois, J. DeEll, K.A. Stewart, and P. Seguin. 2013. Modeling the effect of preharvest weather conditions on the incidence of soft scald in 'Honeycrisp' apples. Postharvest Biol. Technol. 85:57-66.

Lachapelle, M., G. Bourgeois, J.R. DeEll, K.A. Stewart, and P. Seguin. 2017. Modeling the effect of preharvest weather conditions on the incidence of soggy breakdown in 'Honeycrisp' apples. HortScience 52:756-763.

Lara, I., R.M. Mio, T. Fuentes, G. Sayez, J. Graell, and M.L. Lopez. 2003. Biosynthesis of volatile aroma compounds in pear fruit stored under long-term controlled atmosphere conditions. Postharvest Biol. Technol. 29:29-39.

Lee, J., J.P. Mattheis, and D.R. Rudell. 2012. Antioxidant treatment alters metabolism associated with internal browning in 'Braeburn' apples during controlled atmosphere storage. Postharvest Biol. Technol. 68:32-42.

Leisso, R., D. Buchanan, J. Lee, J. Mattheis, and D. Rudell. 2013. Cell wall, cell membrane, and volatile metabolism are altered by antioxidant treatment, temperature shifts, and peel necrosis during apple fruit storage. J. Agr. Food Chem. 61:1373-1387.
Leisso, R.S., D.A. Buchanan, J. Lee, J.P. Mattheis, C. Sater, I. Hanrahan, C.B. Watkins, N. Gapper, J.W. Johnston, R.J. Schaffer, M.L.A.T.M. Hertog, B.M. Nicolai, and D.R. Rudell. 2015. Chillingrelated cell damage of apple (Malus $\times$ domestica Borkh.) fruit cortical tissue impacts antioxidant, lipid and phenolic metabolism. Physiol. Plant. 153:204-220.

Leisso, R.S., N.E. Gapper, J.P. Mattheis, N.L. Sullivan, C.B. Watkins, J.J. Giovannoni, R.J. Schaffer, J.W. Johnston, I. Hanrahan, M. Hertog, B.M. Nicolai, and D.R. Rudell. 2016. Gene expression and metabolism preceding soft scald, a chilling injury of 'Honeycrisp' apple fruit. BMC Genomics 17:798.

Leisso, R.S., I. Hanrahan, J.P. Mattheis, and D.R. Rudell. 2017. Controlled atmosphere storage, temperature conditioning, and antioxidant treatment alter postharvest 'Honeycrisp' metabolism. HortScience 52:423-431.

Little, C.R. and R.J. Holmes. 2000. Storage technology for apples and pears: A guide to production, postharvest treatment and storage of pome fruit in Australia. Department of Natural Resources and Environment, Victoria, Australia. Luo, H.H., J. Song, P. Toivonen, Y.H. Gong, C. Forney, L.C. Palmer, S. Fillmore, X.Q. Pang, and Z.Q. Zhang. 2018. Proteomic changes in 'Ambrosia' apple fruit during cold storage and in response to delayed cooling treatment. Postharvest Biol. Technol. 137:66-76.

Lurie, S. and C.H. Crisosto. 2005. Chilling injury in peach and nectarine. Postharvest Biol. Technol. 37:195-208.

Lyons, J.M. 1973. Chilling injury in plants. Annu. Rev. Plant Physiol. Plant Mol. Biol. 24:445-466.

Miller, E.V. 1936. Distribution of acetaldehyde and alcohol in the apple fruit. J. Agric. Res. 53:4955.

Moggia, C., O. Hernandez, M. Pereira, G.A. Lobos, and J.A. Yuri. 2009. Effect of the cooling system and 1-MCP on the incidence of superficial scald in 'Granny Smith' apples. Chil. J. Agric. Res. 69:383-390.

Moran, R.E., J.R. DeEll, and D.P. Murr. 2010. Effects of preconditioning and fruit maturity on the occurrence of soft scald and soggy breakdown in 'Honeycrisp' apples. HortScience 45:1719-1722.

Nichols, W.C. and M.E. Patterson. 1987. Ethanol accumulation and poststorage quality of 'Delicious' apples during short-term, low $\mathrm{O}_{2}, \mathrm{CA}$ storage. HortScience 22:89-92.

Nyasordzi, J., H. Friedman, Z. Schmilovitch, T. Ignat, A. Weksler, I. Rot, and S. Lurie. 2013. Utilizing the $\mathrm{I}_{\mathrm{AD}}$ index to determine internal quality attributes of apples at harvest and after storage. Postharvest Biol. Technol. 77:80-86.

Pesis, E. 2005. The role of the anaerobic metabolites, acetaldehyde and ethanol, in fruit ripening, enhancement of fruit quality and fruit deterioration. Postharvest Biol. Technol. 37:1-19.

Pierson, C.F., M.J. Ceponis, and L.P. McColloch. 1971. Market diseases of apples, pears and quinces. USDA-ARS Handbook 376. 9 Jan. 2018. $<$ http://postharvest.tfrec.wsu.edu/market>.

Prestage, S., R.S.T. Linforth, A.J. Taylor, E. Lee, J. Speirs, and W. Schuch. 1999. Volatile production in tomato fruit with modified alcohol dehydrogenase activity. J. Sci. Food Agr. 79: 131-136.

Saquet, A.A. and J. Streif. 2008. Fermentative metabolism in 'Jonagold' apples under controlled atmosphere storage. Eur. J. Hort. Sci. 73:43-46.

Smagula, J.M. and W.J. Bramlage. 1977. Acetaldehyde accumulation: Is it a cause of physiological deterioration of fruits? HortScience 12: 200-203. 
Smock, R.M. 1977. Nomenclature for internal storage disorders of apples. HortScience 12:306-308.

Thomas, M. 1931. The production of ethyl alcohol and acetaldehyde by fruits in relation to the injuries occurring in storage: Part II. Injuries to apples and pears occurring in the presence of oxygen and in the absence of accumulations of carbon dioxide in the storage atmosphere. Ann. Appl. Biol. 18:60-74.

Tong, C.B.S., D.S. Bedford, J.J. Luby, F.M. Propsom, R.M. Beaudry, J.P. Mattheis, C.B. Watkins, and S.A. Weis. 2003. Location and temperature effects on soft scald in 'Honeycrisp' apples. HortScience 38:1153-1155.

Wargo, J.M. and C.B. Watkins. 2004. Maturity and storage quality of 'Honeycrisp' apples. HortTechnology 14:496-499.
Watkins, C.B. 2017. Advances in postharvest handling and storage of apples, p. 337-367. In: K. Evans (ed.). Achieving sustainable cultivation of apples. Burleigh Dodds Scientific Publishing, Cambridge, UK. <www.bdspublishing. com $>$.

Watkins, C.B., W.J. Bramlage, and B.A. Cregoe. 1995. Superficial scald of 'Granny Smith' apples is expressed as a typical chilling injury. J. Amer. Soc. Hort. Sci. 120:88-94.

Watkins, C.B., M. Erkan, J.F. Nock, K.A. Iungerman, R.M. Beaudry, and R.E. Moran. 2005. Harvest date effects on maturity, quality, and storage disorders of 'Honeycrisp' apples. HortScience 40:164-169.

Watkins, C.B., J.F. Nock, S.A. Weis, S. Jayanty, and R.M. Beaudry. 2004. Storage temperature, diphenylamine, and pre-storage delay effects on soft scald, soggy breakdown and bitter pit of 'Honeycrisp' apples. Postharvest Biol. Technol. 32:213-221

Watkins, C.B., J.F. Nock, and B.D. Whitaker. 2000. Responses of early, mid and late season apple cultivars to postharvest application of 1-methylcyclopropene (1-MCP) under air and controlled atmosphere storage conditions. Postharvest Biol. Technol. 19:17-32.

Watkins, C.B. and D.A. Rosenberger. 2000. Cornell fruit handling and storage newsletter. 25 Mar. 2018. <http://www.hort.cornell.edu/watkins/ CAnews00.html $>$.

Wills, R.B.H. and K.J. Scott. 1970. Hexanol and hexyl acetate and soft scald of apples. Phytochemistry 9:1035-1036. 